\title{
Současné trendy v diagnostice a screeningu poruch autistického spektra ve Velké Británii
}

\section{Current Diagnostics and Screening Strategies of Autistic Spectrum Disorder in Great Britain}

Štěpánka Lauková, Ústav primární, preprimární a speciální pedagogiky, PdF UHK, Hradec Králové

\begin{abstract}
Abstrakt
Účelem této teoretické studie je přinést informace o současném diagnostickém trendu dětí s poruchou autistického spektra ve Velké Británií. Mnoho studií se zabývá validitou jednotlivých diagnostických nástrojů a jejich spolehlivostí při diagnostice a screeningu poruch autistického spektra (PAS). Právě v Evropě byly poprvé vyvíjeny a používány pruní screeningové nástroje a následně ověřovány v množství studií. Cílem této studie je tedy přiblížit vývoj a současné trendy jedné z vedoucích zemí na tomto poli - Velké Británii. V teoretické studii bude podrobně představen diagnostický proces v raném věku a následně porovná. Účelem je tedy představit propracovaný systém sjednocených diagnostických postupů, které v rámci evidence based practice mohou přinést pozitivní výsledky v zjednodušení postupů při diagnostice poruch autistického spektra $v$ raném věku.
\end{abstract}

\section{Klíčová slova}

porucha autistického spektra, screening, diagnostika, včasný záchyt, přehled, Velká Británie

\section{Abstract}

The purpose of this theoretical study is to provide information on the current diagnostic trend of children with autism spectrum disorder in the UK. Many studies deal with the validity of individual diagnostic tools and their reliability in the diagnosis and screening of autism spectrum disorders (ASD). It was in Europe that the first screening tools were developed and used for the first time and subsequently verified in a number of studies. The aim of this study is therefore to bring the development and current trends of one of the leading countries in this field - the United Kingdom - closer. In a theoretical study, the diagnostic process at an early age will be presented in detail and the results of some studies dealing with the validity and reliability of these screening tools will be compared. The purpose is therefore to present a sophisticated system of unified diagnostic procedures, which, within the framework of evidence based practice, can bring positive results in simplifying procedures for diagnosing autism spectrum disorders at an early age.

\section{Keywords}

autistic spectrum disorder, screening, diagnostics, early detection, review, Great Britain

\section{1. Úvod do problematiky systému speciálního vzdělávání ve Velké Británii}

V první kapitole teoretické studie budou popsány počátky změn v oblasti speciálního školství, jež započali ve Velké Británii v letech 1944-1978. V tomto období se začíná vytvářet systém speciálního vzdělávání, tj. školy, třídy a speciální služby a také následně i samotné vzdělávání učitelů v této oblasti. Děti s různým stupněm postižením získávají právo na vzdělávání a rodiče dětí tedy požadují změny v jejich vzdělávání. Tzv. Warnockova zpráva z roku 1978 (DES, 1978) a zákon z roku 1981 (DES, 1981) následně stanovuje i jasnou definici speciálně vzdělávací potřeby. 
Učitelé působící na běžných školách si začínají uvědomovat, že výuka dětí se zdravotním postižením spadá i do jejich kompetencí. Okolo roku 1980, se objevují názory, že děti s poruchou autistického spektra a Aspergerovým syndromem by měly mít právo být vzdělávány se svými vrstevníky v běžných školách. Žákům s nízkofunkční poruchou autistického spektra pak byla nabídnuta místa ve speciálních školách, a také jednotkách s ústavní péčí, tak aby byly naplněny jejich potřeby (Trevarthen, et al.1998).

S nástupem nové labouristické vlády v roce 1997 byly provedeny významné změny, a to vedlo k lepšímu systému začleňování do běžných škol. Zlepšení zahrnovalo například větší přístupnost programů rané intervence, stanovení cílů pro děti se zvláštními potřebami a přístup k národním osnovám (Letch in Docking, 2000). Lindsay (2003) zpochybňuje důsledky pro ně jako menšinu a tvrdí, že běžný systém nemusí být vhodný a účinný pro všechny děti. Wedell (2005) také považuje hnutí směrem k inkluzi za problematické.

Wedell (2005) uvádí, že začleňování může znamenat mnohé výzvy, například, že ne všechny běžné školy překonávají překážky začleňování, pokud jde o zajištění nezbytných požadavků pro děti se zvláštními potřebami. Školy často chtějí, aby žáci dosahovali vyšších akademických dovedností a cílů, jež by děti se zvláštními vzdělávacími potřebami mohly mít potíže dosáhnout. Podle Wedella (2005) je klíčovým prvkem výuky udržet studenta aktivním účastníkem výuky. Otázkou však zůstává, zda a jak je možné zavést inkluzi, v níž se všichni studenti mohou stát aktivními účastníky?

Na tuto otázku se tedy snaží odpovědět Kodex správné praxe pro zvláštní vzdělávací potřeby (DfE, 1994), který byl zveřejněn v roce 1994 a stanovil přístup k posuzování dětí se speciálními vzdělávacími potřebami a způsob, jakým by měly být jejich potřeby uspokojovány. Kodex podrobně popisuje postupy, které je třeba dodržet, pokud jde o hodnocení žáků se zvláštními potřebami, a to včetně nastavení jejich individuálních vzdělávacích plánů (dále IVP). IVP představují krátkodobé cíle, které mají být zaznamenány a přezkoumány zaměstnanci školy, které jsou poté prezentovány rodičům dítěte. Revidovaný Kodex správné praxe (DfES, 2001) stanovil jasný záměr učinit děti se zvláštními potřebami neoddělitelnými účastníky procesu rozhodování o svých vlastních vzdělávacích cílech a učebních osnovách.

Pawley a Tennant (2008) zjistili, že většina studentů si nebyla vědoma svých IVP, třináct z nich dokonce nevědělo, jaký je význam tohoto pojmu. Jejich studie identifikovala tlaky, které by běžné školy mohly mít na vytváření podstatných IVP. Úřadem pro standardy ve vzdělávání, službách a dovednostech pro děti (OFSTED) a zkušební komisí, což vede k vytváření IVP pro účely inspekce a ne nutně ve prospěch dětí se zvláštními potřebami. Derrington, Evans a Lee (1996) a Clark et al. (1997) však tvrdili, že existuje jasný záměr Kodexu rozdělit odpovědnost mezi další účastníky pracující se žáky se speciálně vzdělávacími potřebami. Těmi účastníky jsou v prostředí britského kurikula především vedení školy, speciální pedagog koordinátor sídlící na základní škole a pracovníci magistrátu pracující v odboru Speciálního vzdělávání. Klíčová koncepce odstraňování překážek bránící dosaženým výsledkům (DfES, 2004) zveřejněná agentury pro odbornou přípravu a rozvoj (TDA), regulačního orgánu vlády Spojeného království pro Přípravné vzdělávání učitelů (ITE) mělo podpořit učení učitelů studentů o inkluzivním systémů, ř́zení chování, hodnocení učení a přístupu ke specializované podpoře (Richards, 2010).

Golderův, Norwichův a Baylisův (2005) výzkum hodnotil program Přípravy budoucích pedagogů (PGCE) pro oblast středoškolského vzdělávání na Univerzitě v Exeteru v Anglii. Jejich závěr podporují Richardsovy (2010) a Winterovy (2006) poznatky o vzdělávání učitelů; podpora studentů v př́ipravných programech jsou důležitou složkou pro zlepšení znalostí učitelů a porozumění relevantní otázky v jejich roli zahrnout děti se zvláštními potřebami do hlavního proudu. Porozumět žákům se speciálními potřebami a přizpůsobit svou práci podle svých individuálních potřeby jsou klíčem k úspěšnému začlenění. Golder, Norwich a Baylis (2005) také dodávají, že znalosti o speciálních vzdělávacích potřebách jsou důležité, ale také zlepšení postojů a přístupu učitelo̊ práce se zvláštními potřebami je životně důležitá.

\section{Vymezení pojmu poruch autistického spektra}

Porucha autistického spektra je zastřešující termín používaný ke skupině řady neurovývojových poruch, včetně autistické poruchy, Aspergerova syndromu, dětské dezintegrační poruchy a všudypřítomné vývojové poruchy - jinak neuváděné. V roce 2013 se některé diagnostické rysy změnily. Před rokem 2013 byl často popisován výskyt diagnostických rysů v triádě, jako hlavní diagnostický moment potvrzující poruchu autistického spektra. Existují však dvě verze této triády: 
1. V Evropě Lorna Wing popsala triádu deficitů v sociální komunikaci, sociální interakci a sociální představivosti.

2. Americká psychiatrická asociace však popsala triádu poruch sociální komunikace, sociální interakce a přítomnosti omezeného a opakujícího se chování a zájmů.

Obě triády tak identifikovaly poruchy sociální komunikace a interakce s jiným důrazem na třetí prvek triády (sociální představivost nebo omezené a opakující se chování nebo zájmy). V roce 2013 Americká psychiatrická asociace navrhla, aby všechny diagnózy související s autismem (např. autismus a Aspergerův syndrom) dostaly na zkrácení označení Porucha autistického spektra nebo ASD. Někteří dospělí s poruchou autistického spektra však tento termín považují za nepřesný a přejí si, aby se místo pojmu porucha používal pojem diagnóza. Ve své studii z roku 2015 se Kelly zaměřil na to, jaký pojem je v souvislosti s používáním preferován právě členy autistické komunity ve Velké Británii. Autoři studie potvrdili zjištění, že univerzální způsob, jak popsat autismus neexistuje. Všechny skupiny však upřednostňovaly pojmy „autismus“, „na autistickém spektru“, a v menší míře „porucha autistického spektra“.

I přesto lze konstatovat významné neshody mezi jednotlivými skupinami, anebo i uvnitř skupin, z nichž mnohé se zdají být do značné míry způsobeny zásadními rozdíly v přesvědčení o autismu a zdravotním postižení v širším měřítku skupiny. Hlavním bodem sporu bylo používání označení, místo autista většina skupin preferuje označení osoba s autismem/Aspergerovým syndromem atd.. Dospělí s poruchou autistického spektra a rodiče dětí s poruchou autistického spektra upřednostňovali termíny pro invalidy (např. „autistické“ nebo „autistické“ osoby“).

\section{Symptomatologie, diagnostika a screening poruch autistického spektra}

I přesto, že u 87 \% dětí s poruchou autistického spektra byly zaznamenány odchylky od běžného vývoje během pravidelných lékařských prohlídek v období do tří let, pouze 43\% z nich obdrželo komplexní vývojová hodnocení. Porucha autistického spektra (PAS) je nervovývojové postižení způsobené rozdílnou funkcí částí mozku. Přesné příčiny zatím nejsou známy. Vědci se domnívají, že existuje několik příčin PAS, které společně mění běžný způsob, jak může vlastní vývoj probíhat.

Porucha autistického spektra se může projevit již před třetím rokem života a přetrvává po celý život člověka, i když příznaky se mohou v průběhu času měnit. Některé děti vykazují příznaky poruchy autistického spektra již během prvních dvanácti měsíců života. U některých dětí se příznaky nemusí projevit až do dvaceti čtyř měsíců, ale i později. Některé děti s poruchou autistického spektra získávají nové dovednosti a pokračují v přirozeném vývoji až do věku 18 až 24 měsíců a poté přestanou získávat nové dovednosti, nebo ztratí dovednosti, které kdysi měly.

Zastřešující diagnóza poruch autistického spektra nyní zahrnuje několik samostatných diagnóz, které byly dříve používány samostatně: autistická porucha, všudypřítomná vývojová porucha, která není jinak specifikována a Aspergerův syndrom. Všechny tyto stavy nyní spadají pod samostatný zastřešující pojem porucha autistického spektra. Aktualizovaná kritéria pro diagnostickou jednotku poruchy autistického spektra zahrnují problémy se sociální komunikací a interakcí a omezené nebo opakující se chování nebo zájmy. Je důležité si uvědomit, že někteří lidé bez diagnostikované poruchy autistického spektra mohou mít také některé z těchto příznaků.

Dovednosti v oblasti sociální komunikace a interakce mohu být narušeny následujícími příznaky, pro ilustraci jsou uvedeny některé příklady charakteristik sociální komunikace a sociální interakce související s poruchou autistického spektra:

$\checkmark$ Vyhýbá se očnímu kontaktu nebo ho neudrží

$\checkmark$ Nereaguje na své jméno okolo věku devíti měsíců

$\checkmark$ Neprojevuje se výrazy obličeje jako je štěstí, smutek, zloba a překvapení ve věku devíti měsíců

$\checkmark$ Nehraje jednoduché interaktivní hry,jako je paci paci do 12 měsíců věku

$\checkmark$ Používá jen málo nebo žádná gesta do 12 měsíců věku (např. nemává na rozloučenou)

$\checkmark$ Nesdílí zájmy s ostatními (např. ukáže vám objekt, který se mu líbí do 15 měsíců věku)

$\checkmark$ Neukazuje ani se na předmět, který je umístěn v jeho zorném poli okolo osmnácti měsíců

$\checkmark$ Nevšimne si, kdyžjiní lidé projeví bolest nebo smutek okolo dvacetičtyř měsíců

$\checkmark$ Neobjevuje se u nějimaginativní hra (např. nepředstírá,že „krmí“ panenku okolo třicátého měsíce věku)

$\checkmark$ Projevuje malý zájem o své vrstevníky 
$\checkmark$ Má potíže pochopit pocityjiných lidí nebo mluvit o vlastních pocitech ve třiceti šesti a více měsíců věku

$\checkmark$ Nehraje hry, kde je nutné střídat hráče okolo šedesáti měsíců věku

Osoby s poruchou autistického spektra mají chování nebo zájmy, které se mohou zdát neobvyklé. Příklady omezených nebo opakujících se zájmů a chování souvisejících s poruchou autistického spektra mohou zahrnovat:

$\checkmark$ Řadí hračky nebo jiné předměty do řad a může se i rozčílit pokud se mu nevede řadu zachovat

$\checkmark$ Opakuje slova nebo fráze (echolalie)

$\checkmark$ Pokaždé si hraje s hračkami stejným způsobem

$\checkmark$ Je zaměřen na určité části předmětů (nap̌̌. kola)

$\checkmark$ Rozčilují ho drobné změny v denní rutině

$\checkmark$ Má obsedantní zájmy

$\checkmark$ Musí dodržovat určité rutiny

$\checkmark$ Klape rukama, kýve tělem, nebo točí dokola

$\checkmark$ Má neobvyklé reakce na to, jak věci znějí, voní, chutnají, vypadají nebo cítí

Další charakteristiky

Většina osob s poruchou autistického spektra má jiné vlastnosti. Mezi ně může patřit:

$\checkmark$ Zpožděné jazykové dovednosti

$\checkmark$ Zpožděné pohybové dovednosti

$\checkmark$ Zpožděné kognitivní nebo výukové dovednosti

$\checkmark$ Hyperaktivní, impulzivní a/nebo nepozorné chování

$\checkmark$ Epilepsie nebo záchvatová porucha

$\checkmark$ Neobvyklé stravovací a spací návyky

$\checkmark$ Gastrointestinální problémy (např. zácpa)

$\checkmark$ Neobvyklá nálada nebo emocionální reakce

$\checkmark$ Úzkost, stres nebo nadměrné obavy

$\checkmark$ Nedostatek strachu nebo více strachu, než se očekávalo

Sociální deficity: Většina dětí, u kterých se autismus rozvine, má potíže zapojit se do každodenních lidských interakcí. Ve věku 8 až 10 měsíců mnoho kojenců, u kterých se autismus rozvine, vykazuje některé příznaky, jako je neschopnost reagovat na jejich jména, snížený zájem o lidi a opožděné žvatlání.

V batolecím období má mnoho autistických dětí potíže s hraním společenských her, nenapodobují činy druhých a raději si hrají samy. Nemusí hledat útěchu nebo reagovat na projevy hněvu nebo náklonnosti rodičủ typickými způsoby.

Poruchy jazyka: Malé autistické děti mají tendenci vykazovat opoždění v předřečových období žvatlání, napodobivého žvatlání a napodobování gest. Některé děti, u kterých se později během prvních několika měsíců života může rozvinout porucha autistického spektra, které broukají nebo žvatlají, mohou toto chování v průběhu vývoje ztratit. Ostatní děti mohou vykazovat významné jazykové zpoždění a řeč se u nich objeví až mnohem později.

Mnoho z nich se postupně naučí používat systémy alternativní a augumentativní komunikace, jako jsou obrázky (např. komunikační systém pro výměnu obrázků nebo VOKS), znakový jazyk, elektronické wordové procesory nebo dokonce zařízení pro generování řeči.

Opakující se chování: Neobvyklé opakující se chování a/nebo tendence zapojit se do omezené škály činností jsou dalším základním příznakem poruchy autistického spektra. Mezi běžné opakující se chování patří třepání rukou, houpání, skákání a kroucení, uspořádání a přeuspořádání objektů a opakování zvuků, slov nebo frází. Někdy je opakující se chování samostimulující, jako je kroucení prsty před očima.

Některé děti tráví hodiny seřazením hraček určitým zpo̊sobem, místo, aby je používaly k imaginativní hře. Opakující se chování může mít podobu intenzivních starostí nebo posedlostí. Tyto extrémní zájmy se mohou ukázat o to neobvyklejší pro jejich obsah (např. ventilátory, vysavače nebo toalety) nebo hloubku znalostí (např. znalost a opakování úžasně podrobných informací o dopravních prostředcích nebo astronomii). Starší autistické děti a dospělí mohou vyvinout obrovský zájem o čísla, symboly, data nebo vědecká témata. 


\section{Screeningové nástroje využívané pro detekci poruchy autistického spektra}

V současné době nemáme lékařský test, který by diagnostikoval poruchu autistického spektra. Místo toho dětští psychiatři a kliničtí psychologové posuzují a hodnotí chování specifické pro poruchu autistického spektra. Rodiče si často jako první všimnou, že jejich dítě vykazuje neobvyklé chování, jako je neschopnost navázat oční kontakt, nereagovat na své jméno nebo si hrát s hračkami neobvyklými, opakujícími se způsoby. Upravený kontrolní seznam poruchy autistického spektra v batolecím věku (M-CHAT-R) je seznam informativních otázek o dítěti. Odpovědi mohou naznačovat, zda by měl být dále hodnocen odborníkem, jako je vývojový pediatr, neurolog, dětský psychiatr nebo klinický psycholog.

Pokud mají rodiče obavy, že jejich dítě může mít poruchu autistického spektra, je možné využít online hodnocení pro děti ve věku 16-30 měsíců. Americká pediatrická akademie (AAP) doporučuje, aby všechny děti absolvovaly screening autismu ve věku 18 a 24 měsíců a M-CHAT-R je jedním z doporučených nástrojů této organizace. Tento screening specificky určený pro detekci poruchy autistického spektra je doplněn o obecná doporučení, jakou cestou se ubírají jednotlivá vývojová stadia ve věku devíti, osmnácti a třiceti měsíců. Efektivní je tedy prověřit všechny děti a tak napomoci tento validní screeningový nástroj jako součást zdravotní dokumentace. Cúlem je, aby navržené screeningové nástroje pomohly rodičům dětí identifikovat a popsat příznaky pozorované u dětí, které mohou znamenat vysoké riziko indikace poruchy autistického spektra. Vývojový pohled na výskyt poruchy autistického spektra zahrnuje dodatečné dotazy na rodiče, zda mají podezření ohledně vývoje nebo chování dítěte, neformální pozorování a sledování příznaků v kontextu denní rutiny dítěte. Vývojový pohled však sám o sobě nestačí k tomu, aby identifikoval děti, které potřebují hlubší posouzení. Děti s poruchou autistického spektra nemusejí často vykazovat charakteristické projevy při krátkých ambulantních vyšetření. Použití standardizovaného screeningového nástroje pro poruchu autistického spektra může rodinám pomoci identifikovat potenciální symptomy. Ve velké studii hodnotící univerzální screening s modifikovaným screeningovým nástrojem M-CHAT se vědci se ptali ošetřujících lékařơ, zda si všimli, nebo měli podezření na výskyt poruchy autistického spektra. Dle výsledků studie byla citlivost a klinické podezření lékařo velmi nízké, pouze třicet ze sto dvaceti tří případů identifikovalo poruchu autistického spektra. Ze studií také vyplývá doporučení o účinnosti univerzálního screeningového nástroje pro tyto potřeby, nebot' jednotný nástroj pomáhá identifikovat příznaky poruchy autistického spektra velmi brzy, a tedy následně celkově zpřesnit diagnózu ve věku osmnácti měsíců. Zwaigenbaum, Bauman a Fein ve své studii z roku 2015 uvádí, že diagnostická stabilita je poměrně vysoká u dětí, kterým byla diagnostikována porucha autistického spektra v období osmnácti až třiceti šesti měsíců. Rané formy screeningu mají tendenci identifikovat pouze mírnější projevy autistického spektra a také zpoždění kognitivní schopnosti, proto je nutné dané děti průběžně pozorovat a dále diagnostikovat následný vývoj. V současnosti nejsou u dětí starších třiceti měsíců validovány žádné screeningové nástroje, které by mohly být využity v praxi pediatry. Nejsou dány ani žádná doporučení pro detekci poruchy autistického spektra v této věkové skupině. Jako využitelný se dle Chesnuta a kolektivu autorů ve studii z roku 2017 jeví Sociální komunikační dotazník (anglicky social communication questionare neboli SCQ), který zkoumá různé druhy populace (např. klinický vzorek, referenční vzorek populace atd.) a výsledky studií ukazují, že nejlepší výsledky dosahuje tato verze ve vzorcích populace a také se zdá, že má přiměřené psychometrické vlastnosti. Schwenk ve své studii uvádí, že dotazníky, jako je Sociální a komunikační dotazník (SCQ), může často identifikovat i symptomy, které se vyskytují v komorbiditě např́klad porucha hyperaktivity a pozornosti ADHD. Další studie potvrzující validitu screeningových nástrojů pro děti starší třiceti měsíců, musí však být ještě dokončeny tak, aby bylo možné potvrdit efektivnost tohoto nástroje. V současnosti patří mezi hlavní doporučení sledování vývoje dítěte odborníky.

Dalším nástrojem screeningu, který by měl být využíván specialisty je Kvocient poruchy autistického spektra (AQ10) pro děti ve věku od 4 do 11 let. Existuje také verze pro žáky ve starším školním věku od 12 do 15 let.

Obrázek dole ilustruje, jaké screeningové nástroje jsou využívány v evropských zemích. Studie probíhají po celé Evropě. Mapa ukazuje studie, které byly k dispozici v letech 2012-2013: 


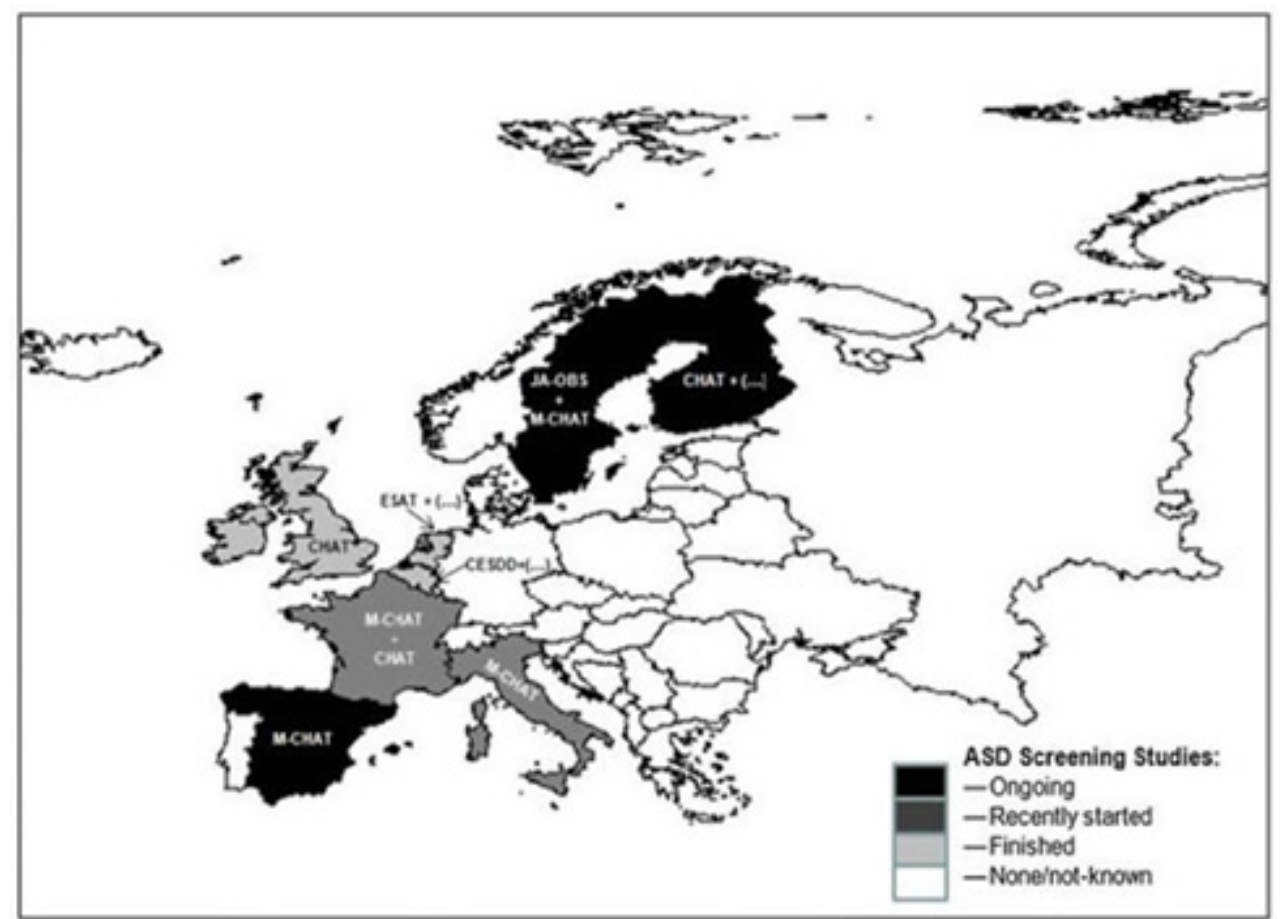

Obrázek č. 1: Mapa probíhajících výzkumŭ ve studii Garcia-Primo a kolektiv autorů, 2014

\section{Diagnostika poruch autistického spektra}

Diagnostické hodnocení by mělo následovat ihned po zachycení možnosti výskytu poruchy autistického spektra. Jak uvádí Daniels (2013), ihned po vzniku podezření by mělo být dítě doporučeno k diagnostickému a klinickému posouzení a dále by měla být nabídnuta služba rané péče. Nebo v závislosti na věku dítěte by mělo dítě obdržet doporučení k speciálně pedagogickému vyšetření. Dětem s vývojovým opožděním s diagnózou poruchy autistického spektra nebo bez ní by měla být doporučena služba rané péče či následné speciálně pedagogické vyšetření, k možnosti dokončení vyšetření úrovně kognitivní a komunikační schopnosti. Úkolem poskytovatele primární péče by mělo být vysvětlení rodině dítěte samotného význam dalších vyšetření a posouzení vývojového stavu, také potvrzení diagnózy poruchy autistického spektra. Dalším úkolem je pomoci rodině při samotném procesu a zprostředkování kontaktů v komunitě osob s poruchou autistického spektra. Speciální pozornost a podporu si zaslouží rodiny s nízkými příjmy, anebo jazykovou bariérou. I přesto je následně nutné, aby bylo dítě vyšetřeno dalším odborníkem, jako je dětský psychiatr, klinický psycholog a dětský neurolog. Včasné potvrzení diagnózy pak může uspíšit i samotné zahájení služeb rané péče a podpory. Jones (2013) uvádí, že v současnosti se nepoužívají a neexistují žádné laboratorní testy, které by bylo možné použít k stanovení diagnózy poruchy autistického spektra, takže je nutné pečlivě přezkoumat historii chování dítěte a posoudit záměrným pozorováním symptomy. Ke splnění diagnostických kritérií je nutné, aby symptomy narušily vlastní funkci. Formální hodnocení jazykových, kognitivních a adaptivních schopností a smyslového stavu je důležitou součástí diagnostického procesu. Dle Gabrielsona a kolektivu (2015) krátké ambulantní návštěvy nemusí umožnit ani zkušenému odborníkovi přesně rozpoznat příznaky poruchy autistického spektra. Přesná anamnéza by měla odrážet dlouhodobé zkušenosti s dítětem, dále odrážet vliv symptomů na schopnost pacienta fungovat v rodinném, školním prostředí a také prostředí vrstevnické skupiny. Tyto informace jsou získány rozhovorem s dítětem, rodiči a zákonnými zástupci, dále zprávami o chování v jiných prostředích (například ve škole) a popisy chování během samotného formálního testování. Contantino, Davis a Todd uvádí, že anamnéza symptomů poruchy autistického spektra může být podpořena dotazníky, jako je Sociální a komunikační dotazník (SCQ) nebo Stupnice sociální odezvy (SRS). Žádný z těchto dotazníků však nemůže být považován za samostatný nástroj k potvrzení poruchy autistického spektra, ale jejich vyplnění a vyhodnocení by mělo být součástí systému hodnocení chování dítěte. Wingová, Leekam, Libby a Gould (2002) uvádí, že Diagnostický rozhovor pro sociální a komunikační poruchy (DISC0) a spolu s kontrolním seznamem chování dětí se používají k posouzení dětí a mládeže pro jiné poruchy chování, ale často mohou zachytit i profil chování vykazující poruchu autistického spektra. Lord, Rutter a Le Couteur (1994) popisují, že v některých ambulantních a výzkumných prostředích je chování spojené s poruchou autistického spektra pozorováno prostřednictvím revidovaného 
diagnostického inventáře autismu (ADI-R), což je delší typ polostrukturovaného rozhovoru s rodiči dítěte. Stupnice sociální odezvy (SRS) je dotazník o šedesáti pěti položkách, který může být použit k měření rysů poruchy autistického spektra na podkladě většího počtu hodnocení. Constantino a kolektiv autorů uvádí, že čím je skóre vyšší, tím je závažnost symptomů poruchy autistického spektra vyšší. Obdobně jsou postiženy i kognitivní schopnosti, komunikační schopnosti a objevují se obtíže v chování. Výhodou strukturovaného pozorování př́znaků poruchy autistického spektra v průběhu diagnostického procesu je i přehled o záznamech o diagnostických kritériích DSM-5.

Dle Dawkinse, Meyere a Van Bourgiena mohou ověřené nástroje pozorování poskytnout strukturované údajů k potvrzení diagnózy a zároveň zahrnují plán pozorování autismu, to vše v souladu s př́istupem evidence based, je tak uvedeno ve druhém vydání Autistické diagnostické a pozorovací škály (ADOS-2) a druhého vydání Stupnice hodnocení dětského autismu (CARS-?). Pro všechny typy diagnostických procesů není vhodný pouze jediný pozorovací nástroj. Nástroje pozorování mají podporovat uplatňování kritérií z manuálu DSM-5 a být obohaceny o další údaje. Diagnostická pozorovací škála ADOS-2 byla vyvinuta tak, aby vyvolávala atypickou sociální komunikaci a chování. ADOS-2 obsahuje moduly specifické pro použití v širší věkové skupině, od batolat až po dospělé. Použití ADOS-2 však vyžaduje intenzivní zaškolení, přesné posuzovaní a skórování. Administrace a vyhodnocení trvá 30 až 45 minut. Velmi často se využívá jako součást výzkumů a klinických posouzení. Informace získané z hodnocení ADOS 2 se pak v kombinaci s vlastní anamnézou vzájemných interakcí, sociálních vztahů a následného funkčního poškození symptomy určí, zda byla naplněna kritéria DSM-5.

Stupnice hodnocení dětského autismu (CARS-2) je dalším strukturovaným přístupem, který může být využit k potvrzení klinické diagnózy poruchy autistického spektra. Úkolem odborníka je dokončit patnácti bodovou stupnici, která je založena na údajích získaných prostřednictvím anamnestický rozhovorů a vlastním pozorování dítěte. Dle studie Rezska, Boyda, McBeeho a Humeho přispěly diagnostické škály a stupnice ADOS-2, CARS-2 a SRS v polovině př́padů k potvrzení diagnózy poruchy autistického spektra. Začlenění informací získaných z anamnestický údajů spolu s objektivním pozorováním klinickým odborníkem zaškoleným v diagnostice poruchy autistického spektra souvisí se získáním informací o diagnostických kritériích uvedených v DSM-5 je kritickým prvkem k potvrzení diagnózy poruchy autistického spektra.

\section{Závěr}

Závěrem lze tedy konstatovat, že pokud je využíváno napříč obory jednotných diagnostických postupů a nástrojů, je možné v průběhu diagnostického procesu výrazně zkrátit dobu jeho trvání a také neustále obohacovat pozorování o nově získané informace. Cílem je provázání jednotlivých složek péče o dítě, at už se nachází v sektoru školství, zdravotnictví nebo sociálních služeb. Nespornou předností je i zvýšení validity jednotlivých diagnostických nástrojů a možnost záchytu většího počtu případů poruchy autistického spektra. Prvním pokusem o sjednocení pozorování by mohl být Edukačně hodnoticí profil dítěte s poruchou autistického spektra z dílen autorek Čadilové a Žampachové, který je v rámci speciálně pedagogické praxe hojně využíván. Dalším krokem by tedy mělo být v rámci větší studie posoudit jeho schopnost zachytit poruchu autistického spektra v raném věku a ověřit s doplňujícími klinickými vyšetřeními, zda zachycení vývojových odchylek následně klinickými diagnostickými nástroji typu ADOS-2 potvrdilo u dítěte poruchu autistického spektra. V neposlední řadě by mělo být také přihlíženo k informovanosti rodičů a zákonných zástupců odborníky, a to i rodičů, jejich mateřským jazykem není čeština. V současné multikulturní společnosti by mělo být příkladem dobré praxe, aby se vysokoškolsky vzdělaní odborníci byli schopni domluvit nejméně jedním ze světových jazyků. Příkladem ideální praxe je pak, aby v jednom ze světových jazyků dokázali posoudit aktuální komunikační schopnosti dítěte. V rámci procesu inkluze je toto jedna z výzev, na které by současná speciálně pedagogická praxe měla reagovat.

\section{Literatura}

Constantino JN, Davis SA, Todd RD, et al. Validation of a brief quantitative measure of autistic traits: comparison of the social responsiveness scale with the autism diagnostic interview-revised. J Autism Dev Disord. 2003;33(4): 427-433 
Corsello C, Hus V, Pickles A, et al. Between a ROC and a hard place: decision making and making decisions about using the SCQ. J Child Psychol Psychiatry. 2007;48(9):932-940

Čadilová, V.; Žampachová, Z.: Edukačně-hodnotící profil dítěte s poruchou autistického spektra. 4. vyd. Praha: Pasparta, 2015. ISBN 978-80-90-5993-6-9.

Daniels AM, Halladay AK, Shih A, Elder LM, Dawson G. Approaches to enhancing the early detection of autism spectrum disorders: a systematic review of the literature. J Am Acad Child Adolesc Psychiatry. 2014;53(2): 141-152

Department for Education [DfE] (1994) Code of Practice on the Identification and Assessment of Special Educational Needs. London: DfE

Department of Education and Science [DES] (1978) The Report of the Committee of Enquiry into the Education of Handicapped Children and Young People (Warnock Report). London: HMSO.

Department of Education and Science [DES] (1981) Education Act. London: HMSO.

Department for Education and Skills [DfES] (2001) Special Educational Needs Code of Practice. London: DfEs

Department for Education and Skills [DfES] (2004a) Removing Barriers to Achievement. London: DfEs.

Derrington, C., Evans, C., \& Lee, B. (1996). The Code in Practice: The Impact on Schools and LEAs. Berkshire: National Foundation for Educational Research.

Docking, J. (2000). New Labour's Policies for Schools - Raising the Standard? London: David Fulton Publishers.

Gabrielsen TP, Farley M, Speer L, Villalobos M, Baker CN, Miller J. Identifying autism in a brief observation. Pediatrics. 2015;135(2). Available at: www.pediatrics.org/cgi/ content/full/135/2/e330

García-Primo, P., Hellendoorn, A., Charman, T., Roeyers, H., Dereu, M., Roge, B., Baduel, S., Muratori, F., Narzisi, A., Van Daalen, E., Moilanen, I., de la Paz, M. P., \& Canal-Bedia, R. (2014). Screening for autism spectrum disorders: state of the art in Europe. European child \& adolescent psychiatry, 23(11), 1005-1021. https://doi.org/10.1007/s00787-014-0555-6

Golder, G., Norwich, B., \& Bayliss, P. (2005). Preparing teachers to teach pupils with specail educational needs in more inclusive schools: evaluating a PGCE development. British Journal of Special Education , 32 (2), 92-99.

Havdahl KA, von Tetzchner S, Huerta M, Lord C, Bishop SL. Utility of the Child Behavior Checklist as a screener for autism spectrum disorder. Autism Res. 2016;9(1):33-42

Herlihy LE, Brooks B, Dumont-Mathieu T, et al. Standardized screening facilitates timely diagnosis of autism spectrum disorders in a diverse sample of low-risk toddlers. J Dev Behav Pediatr. 2014; 35(2):85-92

Chesnut SR, Wei T, Barnard-Brak L, Richman DM. A meta-analysis of the social communication questionnaire: screening for autism spectrum disorder. Autism. 2017;21(8):920-928

Chlebowski C, Green JA, Barton ML, Fein D. Using the childhood autism rating scale to diagnose autism spectrum disorders. J Autism Dev Disord. 2010; 40(7):787-799

JonesRM,LordC.Diagnosing autismin neurobiological research studies.BehavBrainRes.2013;251:113124

Kim SH, Lord C. New autism diagnostic interview-revised algorithms for toddlers and young preschoolers from 12 to 47 months of age. J Autism Dev Disord. 2012;42(1):82-93

Leekam SR, Libby SJ, Wing L, Gould J, Taylor C. The Diagnostic Interview for Social and Communication Disorders: algorithms for ICD-10 childhood autism and Wing and Gould autistic spectrum disorder. J Child Psychol Psychiatry. 2002;43(3):327-342

Lindsay, G. (2003). Inclusive education: a critical perspective. British Journal of Special Education , 30

Lipkin PH, Macias MM; American Academy of Pediatrics, Council on Children With Disabilities, Section on Developmental and Behavioral Pediatrics. Promoting optimal development: identifying infants and young children with developmental disorders through developmental surveillance and screening. Pediatrics. 2020;145(1):e20193449

Lord C, Rutter M, Le Couteur A. Autism Diagnostic Interview-Revised: a revised version of a diagnostic interview for caregivers of individuals with possible pervasive developmental disorders. J Autism Dev Disord. 1994;24(5): 659-685 
Miodovnik A, Harstad E, Sideridis G, Huntington N. Timing of the diagnosis of attention-deficit/hyperactivity disorder and autism spectrum disorder. Pediatrics. 2015;136(4). Available at: www.pediatrics.org/cgi/content/full/136/4/e830

Norris M, Lecavalier L. Screening accuracy of level 2 autism spectrum disorder rating scales. A review of selected instruments. Autism. 2010;14(4):263-284

Pawley, H., \& Tennant, G. (2008). Student perceptions of thier IEP targets. Support for Learning , 23 (4), 183-186

Pinto-Martin JA, Young LM, Mandell DS, Poghosyan L, Giarelli E, Levy SE. Screening strategies for autism spectrum disorders in pediatric primary care. J Dev Behav Pediatr. 2008;29(5):345-350

Reszka SS, Boyd BA, McBee M, Hume KA, Odom SL. Brief report: concurrent validity of autism symptom severity measures. J Autism Dev Disord. 2014; 44(2):466-470

Richards, G. (2010). ,I was confident about teaching but SEN scared me‘: preparing new teachers for including pupils with special educational needs. Support for Learning , 25 (3), 108-115.

Robins DL, Casagrande K, Barton M, Chen CM, Dumont-Mathieu T, Fein D. Validation of the modified checklist for autism in toddlers, revised with followup (M-CHAT-R/F). Pediatrics. 2014; 133(1):3745

Rotholz DA, Kinsman AM, Lacy KK, Charles J. Improving early identification and intervention for children at risk for autism spectrum disorder. Pediatrics. 2017;139(2):e20161061

Sheldrick RC, Perrin EC. Evidence-based milestones for surveillance of cognitive, language, and motor development. Acad Pediatr. 2013;13(6):577-586

Schwenck C, Freitag CM. Differentiation between attention-deficit/hyperactivity disorder and autism spectrum disorder by the social communication questionnaire. Atten Defic Hyperact Disord. 2014;6(3):221-229

Trevarthen, C., Aitken, K., Papoudi, D., \& Robarts, J. (1998). Children With Autism - Diagnosis and Interventions to Meet Their Needs (2nd ed.). London: Jessica Kingsley Publishers.

United Nations Educational, Scientific and Cultural Organisation [UNESC0] (1994) The Salamanca Statment and Framework for Action on Special Needs Education. Paris: UNESCO.

Trevarthen, C., Aitken, K., Papoudi, D., \& Robarts, J. (1998). Children With Autism - Diagnosis and Interventions to Meet Their Needs (2nd ed.). London: Jessica Kingsley Publishers.

Volkmar F, Siegel M, Woodbury-Smith M, King B, McCracken J, State M; American Academy of Child and Adolescent Psychiatry (AACAP) Committee on Quality Issues (CQI). Practice parameter for the assessment and treatment of children and adolescents with autism spectrum disorder. J Am Acad Child Adolesc Psychiatry. 2014;53(2):237-257

Wedell, K. (2005). Dilemmas in the quest for inclusion. British Journal of Special Education, 32 (1), 3-11

Wetherby AM, Brosnan-Maddox S, Peace V, Newton L. Validation of the Infant Toddler Checklist as a broadband screener for autism spectrum disorders from 9 to 24 months of age. Autism. 2008;12(5):487-511

Wing L, Leekam SR, Libby SJ, Gould J, Larcombe M. The Diagnostic Interview for Social and Communication Disorders: background, inter-rater reliability and clinical use. J Child Psychol Psychiatry. 2002;43(3):307-325

Winter, E. (2006). Preparing new teachers for inclusive schools and classrooms. support for Learning , $21(2), 85-91$.

Zwaigenbaum L, Bauman ML, Fein D, et al. Early screening of autism spectrum disorder: recommendations for practice and research. Pediatrics. 2015;136(suppl 1):S41-S59

Zwaigenbaum L, Bauman ML, Stone WL, et al. Early identification of autism spectrum disorder: recommendations for practice and research. Pediatrics. 2015;136(suppl 1):S10-S40

\section{Informace o autorech}

\section{Mgr. Štěpánka Lauková}

Pracuje jako odborná asistentka na Ústavu primární, preprimární a speciální pedagogiky Univerzity Hradec Králové. Jako speciální pedagog působila také jako logoped ve zdravotnictví.

Email: stepanka.laukova@uhk.cz 